\title{
The Concept of the Buddha in Early Buddhism
}

\author{
Guang Xing \\ School of Oriental and African Studies \\ University of London \\ London, WC1H 0XG \\ United Kingdom \\ Email: guang_xing@yahoo.com
}

\begin{abstract}
$^{1}$
Some scholars of Buddhist studies consider the Buddha as a mythological figure. This is especially true at the end of the eighteenth and the beginning of the nineteenth centuries. Later on, rational Buddhist scholars argue that the Buddha is a historical personage and the miraculous stories are actually later additions. In this paper, the author has reexamined the identity of the Buddha by using the earliest Buddhist scripture, namely the Pāli Nikāyas and the Chinese Āgamas. An analysis of the descriptions of the Buddha in these early scriptures reveals two aspects of the concept: a human identity and a superhuman character. These two identities may have co-existed from the inception of Buddhism.
\end{abstract}

Keywords: human Buddha, superhuman Buddha, identity, miracles, great man, supernatural power

In the earliest Buddhist literature, namely the Pāli Nikāyas and the Chinese Agamas, the Buddha is portrayed in two aspects: the human identity and the superhuman, supernormal character. Through the first aspect the Buddha is seen to have constantly interacted with his disciples as well as other religious groups of his time. Through the second aspect, the Buddha is seen as an object of religious worship for his followers, a saviour of the world. ${ }^{2}$ These two aspects intermingled to an extent that it is extremely difficult to separate one from the other without doing injustice to the concept as a whole. More rationalist Buddhist scholars attempt to minimize the "irrational" by claiming that the 
occurrence of miracles in Buddhist literature was due to apocryphal accretion and interpolation. At the same time, some early Western Buddhist scholars may have overstated the superhuman character of the Buddha, asserting that it was simply a solar myth. ${ }^{3}$ After vigorous research into both literary and archeological sources, most Buddhist scholars today accept the historicity of Gautama Buddha. However, the superhuman and supernormal elements of the Buddha may have co-existed from the very beginning of Buddhist literature or even during Gautama's lifetime. It is problematic thus to simply dismiss any of those outright, because all the miracles performed by Gautama as mentioned in the sütras are within six modes of higher knowledge which, according to early Buddhism ${ }^{4}$, can be attained through meditation. According to the sūtras, Gautama confidently believed this to be so. One may even find modern scholars such as Gokhale asserting that such miracles are possible when the mind becomes concentrated and clear through the practice of meditation. ${ }^{5}$ These two aspects of the Buddha may have existed side by side from the inception of Buddhism, and they have served as a foundation for the later development of the concept of the Buddha. In this paper, these two aspects form the subject of inquiry.

\section{The Human Buddha}

The human identity of the Buddha is manifested in the difficulties that he encountered during his lifetime, although they are deeply embedded in legends and mythology. Such examples are his illnesses, his emotions, the troubles within his own community of monks, and his being assaulted and slandered by his enemies. These accounts clearly point to a vivid historical personage who walked on Indian soil as leader of a religious tradition.

\section{1) Human and Physiological Elements}

The Buddha was physically like any other human being, subject to the law of nature that made him vulnerable to fatigue, illness, aging, decay and death as described in the sütras. Instances of the Buddha's illnesses are not rare in the sütras, which describe him as suffering constantly from back pain and stomach troubles. ${ }^{6}$ Both the Pāli and the Chinese versions of the Mahāparinirvānasūtra mention two typical examples of the Buddha's illness which eventually led to his death. ${ }^{7}$ The Pāli commentaries explain that the Buddha suffered backache in old age owing to the severe austerities 
practised during the six years preceding his enlightenment. ${ }^{8}$ Moreover, the unsuitable meals taken during that period were responsible for dyspepsia that persisted throughout his life, culminating in his last serious illness of dysentery. ${ }^{9}$ It is because of all these physical troubles that the Buddha had to consult Jīvaka, the royal physician of king Bimbisāra. ${ }^{10}$ This also is referred to in the Milindapañha. ${ }^{11}$

The Buddha, like any other human being, also slept during the night and ate food in the daytime. This is mentioned in many places in the canon. In order to illustrate this point, we shall cite one example from the Udāna. ${ }^{12}$ A bhikkhu named Sona, who had never seen the Buddha, once came to visit him and spent a night in his company. This monk witnessed what the Buddha had done during that night. The Buddha is described as having spent much of the night in the open meditating and was known to wash his feet before retiring. At dawn of the following morning, he got up and meditated again. ${ }^{13}$ This sort of ablution, as a very common practice in the life of an ordinary human being in those times shows the human side of Gautama Buddha.

The Samyuttanikāya mentions that when the Buddha was old, Ānanda noticed a great change in his physiology. His limbs had become slack and wrinkled, his body bent forward, and a change was to be seen in his sense-faculties too. ${ }^{14}$ In the Mahāparinibbānasutta, the Buddha told Ānanda: "I too, Ānanda, am now old, and full of years, my journey is drawing to its close, I have reached my sum of days, I am turning eighty years of age; and just as a worn-out cart, Ānanda, can be kept going only with the help of thongs, so methinks, the body of the Tathāgata can only be kept going by repairs." ${ }^{15}$ So the body of the Buddha, just as that of any other human being, became weak when he grew old. It was due to all these factors that during his old age Gautama Buddha had to ask Ānanda to become his permanent attendant, the duties of which Ānanda performed with a loving heart and strong faith for twenty-five years. ${ }^{16}$ In his last days, the Buddha's strength quickly ebbed away after his last meal, and according to the Pāli commentary, he had to stop at twenty-five places while travelling three gāvutas ${ }^{17}$ from Pāvā to Kusināra where he finally passed away. ${ }^{18}$

2) Troubles Confronted by the Buddha

No matter how great a religious founder and teacher Gautama Buddha had been as described in 
Buddhist literature, he was not able to completely influence every single individual he had conversed with. He had opponents within his own community of monks such as the well-known Devadatta, who even challenged his authority as the leader of the Samgha and plotted against his life. $^{19}$

The Vinaya frequently mentions a group of monks called Chabbaggiyas ${ }^{20}$ as being guilty of various Vinaya offences. They were known to have attempted to exploit loopholes in the community regulations. $^{21}$ They had led the Buddha to institutionalise many rules concerning the life of a recluse. Assaji, Punabbasu, Paṇuka, Lohitaka, Mettiya and Bhummaja were the leaders of the Chabbaggiyas, and are sometimes referred to in scriptures as 'the six groups' notorious for their misconduct. There were also nuns among their followers, such as Mettiyā, ${ }^{22}$ who likewise had violated the Vinaya rules in various ways. ${ }^{23}$ A serious dispute on Vinaya rules among the Kosambi monks is also found, an incident that could not even be solved by the Buddha, who could only go away. ${ }^{24}$ Therefore, during the Buddha's old age, Kāśyapa complained that it was difficult to speak to the monks for they were intractable and heedless of instructions. ${ }^{25} \mathrm{He}$ told the Buddha that "formerly there were both fewer precepts and more bhikkhus established as arahats, but now there are more precepts and fewer bhikkhus established as arahats." ${ }^{26}$ Even the Buddha could not do anything to prevent it but told Kāśyapa that his teaching would disappear from the world one day in the future.

Some of the Buddha's disciples were dissatisfied with either his teaching or the Buddha himself and left his Order, with some returning to lay life and others joining other śrāmaṇa groups. ${ }^{27}$ Phagguna Bhikkhu was one who was dissatisfied when the Buddha admonished him for misconduct. On another occasion, he put a series of questions to the Buddha who rejected them as wrongly formulated. ${ }^{28}$ Later it was reported that Phagguna returned to lay life. $^{29}$ In a similar case, Arittha was reported to have held a pernicious view and the Buddha rebuked him. As he did not want to give up his view, he returned to lay life when an act of suspension was brought against him. ${ }^{30}$ Sunakkhatta, who once was a personal attendant of the Buddha, became dissatisfied and left the Order because the Buddha did not perform any miracles for him or explain the beginning of the world to him. ${ }^{31}$ 
Some people were attracted by Gautama Buddha and had interesting conversations with him, yet they were not converted because they were suspicious of his claim to enlightenment. On his way to Benares right after his enlightenment, Gautama Buddha met Ājīvaka Upaka, who inquired about his teacher and his Dharma. Gautama Buddha then told him that he had no teacher and he himself was the supreme teacher, the Fully Enlightened One. However, Upaka, the very first person the Buddha met after his enlightenment, shaking his head, went away without being converted. ${ }^{32}$ Dona, the Brahmin, conversed with Gautama on his identity as to whether he was a deva, a gandhabba, a yakkha, or a human being. Gautama declared that he was none other than the Buddha because he destroyed the kleśas, the causes to be born as all these kinds of beings. Dona, however, was not convinced and went away. ${ }^{33}$ This shows that both Upaka and Dona exhibited a thoroughly skeptical attitude towards Gautama's claim to full enlightenment as they both went off without being converted. Just as Naughton states, this reaction seems a very natural one. ${ }^{34}$ The fact that the Pāli suttas portray Gautama Buddha directly after his enlightenment in such an uncomplimentary way is probably good evidence for the authenticity of such an attitude. No later redactor would be likely to fabricate such a story. Similar incidents are also mentioned in the Majjhimanikāya where it is said that although the wanderer Udāyin had conversed with Gautama Buddha on several occasions, he was still not converted. ${ }^{35}$ Daṇdapāni, a Śākya who met the Buddha at Kapilavastu, was also not converted despite the fact that they had an interesting conversation. ${ }^{36}$ According to the Majjhimanikāya commentary, Dạ̣dapāṇi sided with Devadatta, the Buddha's arch foe, and his manner of asking questions was therefore arrogant and deliberately provocative. ${ }^{37}$

According to the Samyuttanikāya, Gautama Buddha encountered other troubles in addition to the incidents mentioned above. He was once refused alms food and had to return with an empty bowl when he went to the Brahmin village, Pañcasālā. ${ }^{38}$ The Dhammapada commentary explains that he actually starved for one day at this village, because none of the inhabitants was willing to offer him alms. ${ }^{39}$ The Vinaya mentions that Gautama was even criticised by the people of Rājagrha for making women childless and widows because a lot of people went forth and renounced the world. ${ }^{40}$ Most of the discourses delivered by the Buddha were received by the audience with delight. Evidence is found at the end of each sütra with the statement that "the bhikṣus are delighted at and accept the Buddha's discourse." However, not all the discourses delivered by Gautama Buddha were happily accepted by his disciples, one example of which is the Pāli Mūlapariyāyasutta. When 
Gautama Buddha delivered this discourse, "the Bhikkhus did not delight in the Blessed One's words." ${ }^{41}$ All these incidents reveal the human identity of the Buddha who had to face all the possible troubles of a religious leader.

\section{3) The Emotions of the Buddha}

It is on rare occasions in the canon that Gautama Buddha showed emotions. But a few cases in the canon suggest that Gautama Buddha felt uneasy and reproached his disciples when they misunderstood and wrongly interpreted his teachings. As the Dharma was his great discovery, his life's work and his message to the suffering world, he would not tolerate his own monks who misrepresented it through carelessness or ill-will. This was the case particularly when their task was to pass this message down to future generations. Sāti, a fisherman's son, is a good example. He wrongly understood the master's teaching that consciousness survived the body and took another form in the new life. Upon hearing this, Gautama cried out: "Foolish man, to whom have you ever known me to teach the Dhamma in that way? Foolish man, in many discourses have I not stated consciousness to be dependently arisen, since without a condition there is no origination of consciousness? But you, foolish man, have misrepresented us by your wrong grasp and injured yourself and stored up much demerit." ${ }^{42}$ Aritthha, a former vulture-trainer, was another monk who was reproached by the Buddha in a similar manner for his misunderstanding of the Dharmavinaya. The Buddha blamed him for being a foolish and misguided man. ${ }^{43}$ The commentary explains that while reflecting in seclusion, Arittha came to the conclusion that there would be no harm for bhikṣus to engage in sexual relations with women, and he therefore maintained that this should not be prohibited by the monastic rules. ${ }^{44}$ In both cases the monks were of humble origins and probably did not have any education at all, so they had difficulty in understanding the Buddha's teaching in its philosophical dimensions. But the two topics concerning a fundamental doctrine and a fundamental practice are crucial in the understanding of the Buddha's teachings. It therefore appears that the Buddha reproached them with personal feeling.

In these two cases, it may perhaps be argued that the Buddha was not angry, but what he said concerning Devadatta suggests that he was angry at least in the literary sense of the word. Devadatta intrigued for the leadership of the Samgha and asked the Buddha to hand over it to him. 
The Buddha said: "Not even to Sāriputta and Moggallana would I hand over the Order, and would I to thee, vile one, to be vomited like spittle?" 45 In the Anguttaranikāya, we find the following saying of Gautama Buddha when Ānanda made inquiries on Devadatta: "And so long as, Ānanda, I saw a bright spot in Devadatta, even the prick-end of a horse-hair in size, I declared not: 'Devadatta is wayward gone, hell-bound for a kalpa, unpardonable' - but it was when I saw none, that I declared thus..." ${ }^{46}$ The same comment is also found in the Chinese counterpart, the Ekottarägama. ${ }^{47}$ This statement is not unlike a curse, and arguably motivated by anger. The Devadatta incident was a bitter experience in the life of Gautama Buddha, because as a monk and disciple in his own community, Devadatta had tried with a certain success to split the Order the Buddha had established with much effort. Therefore, whenever Devadatta was mentioned, Gautama Buddha would speak of him as a bad person of evil intention.

The Samgha was the disseminator of the Buddha's message to the world. Gautama was very concerned about the split of the Samgha for he had seen what had happened to Jaina monks in the last few years of his life. ${ }^{48}$ The Vibhāṣa , with reference to Devadatta, mentions that the bad karma entailed by the destruction of the Samgha is graver or heavier than that of shedding the blood of the Buddha. The split of the Samgha was explained as the destruction of the dharmakāya while shedding the blood of the Buddha harms the rūpakāya. ${ }^{49}$

Apart from these, there are at least two cases in the Mahäparinibbānasutta that illustrate the Buddha displaying emotions. These consisted in feeling appreciation towards beautiful things. The first incident was when the Licchavis of Vesālī, wearing cloths of different colours and adorned with various kinds of ornaments, approached the Buddha in carriages. Gautama said to his disciples: "O brethren, let those of the brethren who have never seen the Tāvatimsa gods, gaze upon this company of the Licchavis, behold this company of the Licchavis, compare this company of the Licchavis, for they are even as a company of Tāvatimsa gods." ${ }^{50}$ The second incident occurred after the Buddha and Ānanda had returned from a begging tour in Vesālī. The Buddha addressed Ānanda: "How delightful a spot, Ānanda, is Vesāli, and how charming the Udena Shrine, and the Gotamaka Shrine..." ${ }^{51}$ These two incidents are also mentioned in the Chinese translations of the Mahāparinirvānasūtra. ${ }^{52}$ These pieces of literature suggest that the Buddha had emotions which he manifested in different ways. If a sense of appreciation shows the compassion of Gautama Buddha, 
then anger definitely shows the human side of him because a Buddha, at least by definition, is a person who has eliminated the three evils: greed, hatred and ignorance. These incidents reveal the human aspect of the Buddha.

\section{4) Slander and Assaults from Enemies}

There are two incidents concerning the Buddha being slandered by his opponents in early Buddhist literature and they are referred to in the Pubbakammapiloti of the Apadāna as the remaining effects of the bad karma done by the Buddha in his previous lives. ${ }^{53}$ First, Ciñcamānavikā, a beautiful female ascetic ${ }^{54}$ from another Order, was persuaded by her fellow ascetics to discredit the Buddha because they found that their gains had diminished due to the popularity of the Buddha. She pretended to have become pregnant by the Buddha by tying a wooden disc around her body and went to where he was addressing a large congregation. Her accusation was soon found out to be false and she was chased out by the audience. ${ }^{55}$ The second story is recorded in the Udana about Sundarī, also a female ascetic ${ }^{56}$ from another Order, who was persuaded by her fellow ascetics to insult the Buddha and his disciples. She visited Jetavana where the Buddha was residing and pretended to have stayed in the evenings and left in the mornings. After some days, the heretic ascetics hired some villains to kill Sundarī and hide her body under a heap of rubbish near Jetavana. When this was reported to the king, a search was carried out and her body was found. Her fellow ascetics then went about the streets of the city crying: "Behold the deeds of the Śākya monks." ${ }^{57}$ These two incidents simply suggest that the Buddha suffered slanders in his life time and hence they show the human aspect of him.

This analysis of the Buddha's physical illness, troubles in life, emotions and assaults from enemies suggests that he was a human teacher and guide who had suffered all the possible difficulties of a great man within his own community, as well as from outside opponents. It is from this human aspect of the great teacher as described in early Buddhist literature, that the Sarvāstivāda and other Hīnayāna schools formulated their concept of a human Buddha.

2. The Superhuman Buddha 
In the descriptions of the same early Buddhist literature, Gautama Buddha is also associated with various kinds of miracles, either performed by him or which occurred naturally to mark special events in his life. Apart from miracles, his physical body is described as having the thirty-two marks of a great $\operatorname{man}^{58}$. This superhuman character plays a special and important role in the life of Gautama Buddha as a religious leader and founder. It is possibly due to the tendency to idealize the Buddha that this phenomenon emerged, probably as early as during the lifetime of Gautama.

\section{1) The Physical Marks}

The Lakkhanasutta of the Dighanikāya and the Brahmāyusutta of the Majjhimanikāya mention that the Buddha had thirty-two physical marks of a great man, ${ }^{59}$ and this is also confirmed by the Chinese Agamas. ${ }^{60}$ But scholars are of the opinion that the concept of a great man is pre-Buddhistic and the tradition was adopted from Brahmanical tradition and applied to the Buddha when the latter was idealized. ${ }^{61}$ There are two reasons for this assertion. Firstly, the Buddhist concept of a great man is in a spiritual rather than physical sense because the Buddha reinterpreted the concept of the mahäpurisa and gave it a new meaning as he had done with other concepts such as karma. Scholars have collected the passages concerning the term mahāpurisa in the Pāli canon and pointed out that it was used in an ethical way for one who possessed an emancipated mind, ${ }^{62}$ and one who had destroyed all defilements. ${ }^{63}$ In the Anguttaranikāya, the definition of a mahāpurisa is as follows: one who has concerned oneself with the welfare of the great mass of people, having the mastery of thought, the ability to enter the four ecstasies that are beyond thought yet pertaining to the present life, and one that discarded intoxication arising from lust, as well as becomings from speculation and ignorance. ${ }^{64}$ In this sense, an arhat could also be called a mahāpurisa. ${ }^{65}$ However, the faithful followers seemed to have forgotten or rather ignored this fact, and attributed to the Buddha a list of thirty-two physical marks. ${ }^{66}$ Secondly, the Brahmāyusutta of the Majjhimanikāya mentions that it was the Brahmin Brahmāyu, learned in the three Vedas and versed in the marks of a great man, who sent his pupil Uttara to examine the Buddha about his physical marks. ${ }^{67}$ The Selasutta of the Suttanipāta states that the tradition of the marks of a great man had been handed down in the Brahmin hymns. ${ }^{68}$ This is a direct reference to the concept of a great man in the Brahmanical tradition. 
In addition to the thirty-two marks, Gautama Buddha is also described as having an attractive and penetrative voice of eight qualities: distinct, intelligible, melodious, audible, ringing, euphonious, deep, and sonorous. ${ }^{69}$ It is perhaps on this basis that the Mahāsāmghikas further interpreted that the Buddha only spoke in one voice but sentient beings understood it according to their inclinations. ${ }^{70}$ In the Mahaparinirvañasūtra, the hue of the Buddha's skin is described as exceedingly bright the night before he passed away, as even the burnished cloth of gold had lost its splendour when he wore the robe. ${ }^{71}$ This has been taken up by the Mahāyānists as an important topic and developed as the physical light of the Buddha.

Although it is stated in the sūtras that the Buddha had all these distinguishing bodily features, he was not necessarily recognised by ordinary people when he walked about on the road. ${ }^{72}$ The Dhātuvibhaingasutta of the Majjhimanikāya mentions that Pukkusāti renounced the world under the name of the Buddha but he had never seen him before. He could not recognise the Buddha when they met in a potter's hut and apologised for calling him 'avvuso ${ }^{13}$ which is a term used for addressing equals. ${ }^{74}$ Walpola Rahula says that in early Buddhism, a disciple addressed his master usually by the term bhande, which approximately means 'Sir' or 'Lord'. ${ }^{75}$ The Upakkilesasutta of the same Nikāya mentions another example of the Buddha being indistinguishable from other monks in physical appearance. Gautama Buddha, after having left the Kosambī monks, came to the park where venerable Anuruddha and two other fellow monks were staying. The park keeper did not recognise the Buddha by his physical appearance and asked him not to enter the park because there were three mendicants practising seriously. ${ }^{76}$ The same incident is also found in the Chinese Ekottarāgama. ${ }^{77}$ In these two instances, had the Buddha possessed the thirty-two bodily marks of a great man, they would certainly have recognised him at a glance. His long arms that could reach to his knees without bending, for instance, constitute visible signs. This suggests that the faithful followers must have added these physical attributes to the Buddha in the course of time in order to glorify him. The historical Buddha might not have them at all. Moreover, as W. Pachow indicates, these marks do not actually enhance the real importance of the Buddha as an enlightened teacher. ${ }^{78}$

\section{2) Miracles}

The miracles associated with Gautama Buddha are traditionally reckoned as belonging to the 
adbhuta-dharma of the nine or twelve divisions ${ }^{79}$ of the Buddhist scripture. ${ }^{80}$ They are found in various occurrences in early scriptures. (1) The Ariguttaranikāya mentions an immense light that manifested on four occasions in the life of the Buddha: at the time of his descent from Tusita Heaven, his birth, his enlightenment and his first public preaching. ${ }^{81}$ (2) The Acchariyābbhūtasutta of the Majjhimanikāya is an account of twenty miracles of the Buddha at his birth as extolled by Ānanda, such as an earthquake; two streams of water, one cool and one warm, pouring down from heaven to bathe him; and infinite light. ${ }^{82}$ (3) Both the Ariguttaranikāya and the Chinese Madhyamāgama mention an earthquake before the Buddha's passing away which is also mentioned in all the versions of the Mahāparinirvānasūtra. ${ }^{83}$ (4) The Iddhipāda-Samyutta mentions six modes of supernatural power ${ }^{84}$ of the Buddha which he gained through meditation. ${ }^{85}$

The fact that the miracles of the Buddha are reckoned as adbhuta-dharma by the early compilers of Buddhist scriptures suggests that from the very beginning these wondrous things were looked upon as special events. These miracles can be divided into two groups: (1) the supernormal events that occurred naturally to mark the special occasions in the life of the Buddha such as his birth, enlightenment and death, and (2) the supernormal acts performed by Gautama Buddha himself.

The first group of supernatural events occurred on many important occasions in the life of Gautama Buddha, namely his birth, his enlightenment, his first sermon and his death. The Acchariyābbhūtasutta of the Majjhimanikāya describes a series of miracles that happened to mark the birth of the Buddha. It is perhaps for the faithful devotees that the birth of the Buddha on earth was the most marvellous event to be remembered. Other supernatural events fall primarily into two categories: those pertaining to light and those pertaining to earthquakes. Gokhale remarks that these events are explained as the result of dharmata, the nature of things, implying that they were not causally connected with the Buddha, but had occurred because of the nature of things. ${ }^{86}$ The special events in the life of Gautama Buddha were certainly extraordinary occasions for his faithful followers or even his immediate disciples, and most likely they were persuaded that these should be marked by extraordinary occurrences in nature. However, these events do not affect the attainments and achievements of the Buddha, but only suggest that he was not an ordinary being.

The second kind of miracle is important in our study. It falls within the power of the six modes of 
higher knowledge ${ }^{87}$ that not only the Buddha, but anyone who had attained the higher concentration or the four dhyānas could perform them such as an arhat. ${ }^{88}$ This is described in detail in the Sämañ̃naphalasutta as the fruit of the samana's life. ${ }^{89}$ The six modes of higher knowledge are (1) supernatural power, ${ }^{90}$ (2) the divine ear, ${ }^{91}$ (3) penetration of the minds of others, ${ }^{92}$ (4) memory of former existences, ${ }^{93}$ (5) the divine eye, ${ }^{94[}$ and (6) extinction of all cankers. ${ }^{95}$ According to the Sämañ̃naphalasutta, these six modes of knowledge are in an ascending order and the knowledge of the extinction of all cankers is the highest which can be attained only by a Buddha, a pratyekabuddha and an arhat. The first five are mundane and the last is supramundane, thus it is only through acquiring the sixth knowledge that one becomes emancipated.

The Buddha, according to the Mahāsaccakasutta, had attained three kinds of knowledge on the night of his enlightenment: he perceived his own past lives, he saw the past lives of other beings, and he knew that his cankers were destroyed. ${ }^{96}$ These three knowledges correspond to the fourth, the fifth and the sixth of the six modes of higher knowledge.

Most of the miracles performed by the Buddha as mentioned in the sütras and vinaya belong to the first category, that of supernatural power. ${ }^{97}$ The Vinaya describes many miracles performed by the Buddha right after his enlightenment: the miracle of hiding Yasa so that his father could not see him, and the series of miracles to convert the three Kāśyapa brothers. ${ }^{98}$ The Mahäparinirvānasūtra mentions three miracles performed by Gautama Buddha through the use of his supernatural power ${ }^{99}$ : the crossing of the Ganges River as fast as a strong man would stretch forth his arm; ${ }^{100}$ extending his life-span to a kalpa or to the end of the kalpa if desired; ${ }^{101}$ and making turbid water clear. ${ }^{102}$ The Majjhimanikāya also mentions three miracles of the Buddha: vanishing without a trace in front of Brahmā, ${ }^{103}$ walking at his normal pace while Angulimāla could not catch up even at full speed, ${ }^{104}$ and showing his male organ with a supernatural feat. ${ }^{105}$ There are more examples in the canon but it is unnecessary to mention them all. According to the Sampasādaniyasutta of the Dighanikāya, supernatural power is ignoble if it is used for worldly aims and purposes, but it is noble if it is used for a higher and virtuous aim. ${ }^{106}$ These powers had little or nothing to do with the realisation of the highest goal of nirvāna, and it is for this very reason that Gautama implemented monastic rules to prohibit any display of miracles. He considered such displays to be similar to a respectable woman flaunting her womanly tokens in public. ${ }^{107}$ When converting an individual, 
Gautama Buddha almost always enjoyed using rational persuasion, which is called ānusāsan̄ pātihāriya, the miracle of education or instruction. The instance of converting the three Kāśyapa brothers is perhaps the only example recorded in the entire Pāli canon when Gautama used supernatural power. This happened at the very beginning of his public ministry when he had no influence at all in religious circles. Hence, it might have been for pragmatic reasons that Gautama had to resort to the power of $r d d h i$, if he possessed any, to convert these three renowned hair-matted ascetics.

The genuine belief that Gautama Buddha possessed those six modes of higher knowledge most probably existed during his lifetime, and all his arhat disciples were also believed to have such knowledge. Maudgalyāyana, who was renowned for his $r d d h i$ power, is a good example. Gokhale also says: "There is reason to believe that Gotama, in the context of his times, accepted without demur, the validity of knowledge gained by extrasensory perception and the ability of a human being to exercise supernatural and supernormal powers by the strength of his will cultivated to an extraordinary extent." ${ }^{108}$ Although this may be difficult to accept from a modern academic perspective, it is not simply irrefutable. More acceptable and relevant is that these six modes of higher knowledge distinguish Gautama Buddha from others. However, he did not claim a monopoly of them, but stated rather that anyone could achieve them by means of earnest practise. In comparison to the supernatural events that manifested spontaneously, the six higher modes of knowledge of the Buddha likely belong to the earlier strata in the Buddhist canon. This suggests that the superhuman character of the Buddha had existed side by side with his human aspect in early Buddhism.

In addition to the six modes of higher knowledge, both the Nikāyas and the Agamas mention that the Buddha had ten powers and four kinds of intrepidity. ${ }^{109}$ The Sarvāstivādins asserted that these are the exclusive qualities of the Buddha not shared with arhats although they are all equal in terms of liberation. However, as the term 'exclusive' is not mentioned in the relevant sütras, the compiler of the Mahāprajãāpāramitāśāstra states that these qualities are in fact shared with arhats. Therefore, in the process of idealisation of the Buddha, these qualities along with great compassion $^{110}$ and the three bases of mindfulness were termed 'the eighteen exclusive qualities' of the Buddha. The 'eighteen exclusive qualities' is likely to have had an apocryphal function to 
distinguish the Buddha from other liberated individuals although they are found individually in the early scriptures.

It is clear from this analysis that the concept of the Buddha in early Buddhism holds two aspects: the human identity and the superhuman character. It is most probable that on the basis of the human elements of the Buddha, the Sarvāstivādins formulated their concept of the Buddha as a human being. On the other hand, the Mahāsāmghikas had conceived their transcendental Buddha on the basis of the superhuman or divine powers, because they were the faithful and accepted whatever was said in the sūtras. This does not necessarily imply that the Sarvāstivādins did not accept the superhuman aspects of the Buddha, but that they considered it with increased caution. Vasumitra's treatise mentions that they did not take every word of the Buddha as the teaching of Dharma.

${ }^{1}$ There are some Chinese characters and Romanized Sanskrit terms in this paper. If your computer does not support these characters, please download the relevant fonts and install them first. To download GBK Chinese font to browse with IE, please click here. To download Sanskrit font to browse with IE, please click here.

2 The Acchariyābbhūtasutta of the Majjhimanikāya mentions that soon after the Buddha was born he said: "I am the highest in the world; I am the best in the world; I am the foremost in the world. This is my last birth; now there is no renewal of being for me." (Majjhimanikāya iii, 123) This clearly shows that the Buddha was an almighty saviour.

3 These scholars include M. Senart, Essai sur la legende du Buddha, Paris, 1875, and also Heinrich Kern, A. Barth, R. Otto and Ananda Coomaraswamy.

4 The term "Early Buddhism" indicates the teachings of the Buddha as revealed in the Pâli Nikāyas and the Chinese Āgamas which are considered by scholars as the earliest form of Buddhist literature.

5 B. G. Gokhale, New Light on Early Buddhism. London: Sangam Books Limited, 1994, pp.107-108.

6 The Sekhasutta of the Majjhimanikāya (i, 354.) records that the Buddha suffered from back pain and asked Ānanda to speak on higher training. Similarly, Moggallāna (Samyyuttanikāya iv, 183-4. T2, 316b), Sāriputta (Dīghanikāya iii, 200; Taisho Volume 1, 49c; Añguttaranikāya v, 122; 125), and Anuruddha (Taisho Volume 1, 551c-552b) were asked to preach on his behalf under similar circumstances. Stomach troubles of the Buddha are mentioned in many places in the canon 
such as Vinaya, ii, 210; Theragāthā, 185; Samyuttanikāya i, 174-5. It is also found in the Dhammapada commentary, iv, 232 and the Theragāthā commentary, I, 311.

7 The Pāli version, Dīghanikāya ii, 127-8, the four Chinese translations: Taisho Volume 1, 18b, $164 \mathrm{c}, 180 \mathrm{a}, 197 \mathrm{~b}$.

8 The Mahjjimanikāya commentary, i, 465 and the Dīghanikāya commentary, iii, 974.

9 The Samyuttanikāya commentary, i, 200.

10 Vinaya, i, 279.

11 Milindapañha, i, 135.

12 The Udāna, 165-67.

13 The Samyuttanikāya mentions that the Buddha sometimes walked a great part of the night and then washed his feet before going to bed. Samyuttanikāya, i, 106.

14 Samyuttanikāya, v, 217.

15 Dighanikāya ii, 100. The English translation is adopted from Rhys Davids's The Dialogues of the Buddha, II, p.107. This is also mentioned in three of the Chinese translations of the Mahāparinirvānasūūtra: Taisho Volume 1, 15b, 164c, 180a.

16 Taisho Volume 1, 472a. This sūtra must belong to a very late date since it contains praises of Ānanda as an attendant of the Buddha for twenty-five years. A similar account of it in the Southern Tradition is found in the commentary on the Dhammapada.

17 approximately eight to twelve miles

18 The Dïghanikāya commentary, ii, 573. For an explanation of the term gāvuta see An Yang-Gyu, 'Buddhology in the Mahāparinibbāna Suttanta and Its Commentary, With an Annotated Translation of Buddhaghosa's Commentary'. Unpublished PhD Dissertation submitted to the Faculty of Oriental Studies, University of Oxford, 1998, 257, footnote 2.

19 Vinaya, ii, 257-71. Samyuttanikāya, i, 262.

${ }^{20}$ According to the Samantapāsāalikā (iii, 613f.), they were all from S vatthi and were originally acquaintances. Finding a living hard to obtain, they entered the Order under the two chief disciples. They decided among themselves that it was unwise for them all to live in the same place, and they therefore divided themselves into three groups. Each group had five hundred monks attached to it. Of the three groups, the followers of Paṇuka and Lohitaka were the most virtuous. Unlike the others, they did not transgress Vinaya rules.

21 The Pāli Vinaya, Vol.i, 84f., 104, 106, 111, 113, 114, 138, 160, 170, 185, 189, 192, 194, 
203f., 216, 285, 306, 316; Vol. ii, 73, 105ff., 145ff., 213ff., 241, 262, etc. The Chinese Tripi aka: Taisho Volume 1, 191, 217, 360; Taisho Volume 3, 149; the Dhammapada commentary, iii, 48f., $330,382$.

22 T2, 279c. Cullavagga. iv, 4. 4-11. The nun Mettiyā was persuaded by her brother Mettiyabhummajakā to accuse Dabba Mallaputta of having an affair with her. After an investigation, it was found to be false.

23 Vinaya, ii, 262, 266, 269, 271, 276.

24 Majjhimanikāya, iii, 153.

25 Samyuttanikāya, ii, 208. T2, 300c-301a.

${ }^{26}$ Samyuttanikāya, ii, 223-4.

${ }^{27}$ Mahāvagga, i, 31.

28 Samyuttanikāya, ii, 13.

${ }^{29}$ Samyuttanikāya, ii, 50. There is another case of returning to lay life in Samyuttanikāya, iv, 102.

30 Cullavagga, i, 32-34. The story of Arittha is also found in Majjhimanikāya, i, 130.

${ }^{31}$ His defection is given in the Pạtikasutta of the Dighanikāya and his return to lay life is given in the Mahāsīhanādasutta of the Majjhimanikāya, i. 68. The Sunakkhattasutta (Majjhimanikāya, No.105) apparently expounded to him by the Buddha before he joined the Order.

${ }^{32}$ Majjhimanikāya, i, 170-171. Taisho Volume 1, 777b. During the time of the Buddha, people judged whether a person was or not an Arhat by their serenity of countenance which is an expression of the inner peace. For instance Sāriputta took Assaji as an enlightened person due to his appearance (Vinaya, i, 40).

33 Anguttaranikāya, ii, 36-37. Taisho Volume 2, 28a-b.

34 A. Naughton, 'Buddhist Omniscience'. Eastern Buddhist, vol.24, No. 1, 1991, p.32.

35 The discussions held between Gautama Buddha and the wanderer Udāyin are found in the Mahāsakuludāyisutta and the Cūlasakuludāyisutta, numbers 77 and 79 of the Majjhimanikāya. There are several Udāyins mentioned in the Nikāyas. According to Mrs Rhys Davids, (Psalms of Brethren, Pali Text Society, 288, footnote 2) there are three Udāyins who are the disciples of the Buddha: Kāludāyin, Udāyin the great, and a Brahmin Udāyin. The person in our discussion is a wanderer Sakuludāyin.

${ }^{36}$ Majjhimanikāya, i, 108. Taisho Volume 1, 603b; T2, 743a. 
37 Cited from The Middle Length Discourse of the Buddha, tr. Nānamoli. Boston: Wisdom Publication, 1995, endnote 226.

38 Saṃuttaranikāya, i, 112. Taisho Volume 2, 772a-b.

39 The Dhammapada commentary, iii, 257.

40 Vinaya, i, 39-44.

${ }^{41}$ Majjhimanikāya, i, 6.

42 Majjhimanikāya, i, 258.

43 Majjhimanikāya, i, 132.

44 This is referred to in The Middle Length Discourse of the Buddha, endnote 249.

45 Vinaya, ii, 188, "Sāriputtamoggallānānam pi kho ahạ̣ Devadatta bhikkhusaṃgham na nissajjeyyaṃ, kim pana tuyhạ̣ chavassakhelāpakassā'ti". It is also mentioned in the Dharmaguptakavinaya (Taisho Volume 22,592b, 我向不以僧付舍利弗、目連, 況汝癡人涕唾之 身? 豈可付囑?), the Daśabhānavāravinaya, (Taisho Volume 23, 258b, 舍利弗、目連有大智慧、 神通, 佛向不以衆僧付之, 況汝啖唾癡人、死人而當付囑? ), the Mūlasarvāstivādavinaya (Taisho Volume 23, 701c, 汝之癡人, 如舍利子、大目連, 我向不以苾忽僧伽而見付囑, 況汝癡人、食 人洟唾而相付囑? ), the Mūlasarvāstivādavinaya Sanghabhedavastu (Taisho Volume 24, 169b, 如 我舍利弗、大目揵連, 弟子中學, 聰明智慧、梵行神通證羅漢果, 我今劣自不以苾忽僧伽而 見付囑, 豈可況汝無智癡人食唾者乎? ). This incident is also referred to in the Abhayarājakumārasutta (Majjhimanikāya, i, 393). The sense and meaning of the quotation are basically the same in the Vinaya of all these schools and traditions although the wording and expression are slightly different. This suggests that it is probably historical in nature.

46 Anguttaranikāya, iii, 401.

47 Taisho Volume 2, 567a-c.

48 According to the Sāmagāmasutta (Majjhimanikāya, ii, 243-244), in his last few years, the Buddha observed that Jain monks split after the death of their Master because of different views and understandings on the teachings of their Master.

49 Taisho Volume 27, 601c-602a.

50 Dīghanikāya, ii, 96.

51 Dìghanikāya, ii, 102. It is also mentioned in the Samyuttanikāya, v, 258.

52 The praise of the Licchavis is mentioned in all the four Chinese versions: Taisho Volume 1, 13c, 164a, 179b, 194b, but the praise of the city of Vesāli is only found in two: Taisho Volume 1, 
$165 \mathrm{a}, 180 \mathrm{~b}$.

53 Apadāna, i, 299-301.

54 paribhājikā

55 Apadāna, 299-301, verse: 7-9; Jātaka, iv, 187f.; Dhammapada commentary, iii, 178f.; Itivuttaka commentary, 69.

56 paribhājikā

57 The Udāna, iv, 8; the Udāna commentary, 256ff.; the Dhammapada commentary, iii, 474f.; the Samyutta commentary, ii, 528f.; the Jätaka, ii, 415f.; and the Apadāna, 299-301, verse: 4-6. According to the commentary of the Majjhimanikāya, this is also referred to in the Bāhitikasutta of the Majjhimanikāya that King Pasenadi inquired Ānanda about it.

58 mahāpurisa

59 mahāpurisa

${ }^{60}$ The thirty-two marks of a great man are mentioned in many early sūtras: the Pāli suttas such as the Mahāpadānasutta of the Dìghanikāya, ii, 17-19; the Lakkhanasutta of the Dīghanikāya, iii, 143-144; the Brahmāyusutta of the Majjhimanikāya, ii, 136-137; the Chinese translations such as the Dìrghägama, Taisho Volume 1, 5a-b; the Madhyamāgama, Taisho Volume 1, 686; 883c-884a; the Sanghabhedavastu of the Mülasarvāstivādavinaya, Taisho Volume 24, 108c-109a and the Mahāvastu, i, 226; ii, 29.

${ }^{61}$ Hajime Nakamura, for instance, Gotama Buddha - Shakuson no Shōgai (Gotama BuddhaThe Life of Śākyamuni), 513.

62 vimuttacitta

63 T. W. Rhys Davids, The Dialogues of the Buddha, iii, 134-135. T. Endo (1997), 139-140. The passages concerning the mahāpurisa are found in the Samyuttanikāya, v, 158, the Suttanipāta, verse No. 1040-1042, and the Dhammapada, verse No. 352.

${ }^{64}$ Anguttaranikāya, ii, 35.

65 Dhammapada, verse 352.

${ }^{66} \mathrm{H}$. Nakamura is of the opinion that it is the Buddhists who first formulated the list of the thirty-two marks. Cited from T. Endo, Buddha in Theravāda Buddhism, A Study of the Concept of Buddha in the Pāli Commentaries. Colombo: The Buddhist Culture Center, 1997, 139.

67 Majjhimanikāya, ii, 133-134.

${ }^{68}$ Suttanipāta, 106. 
${ }^{69}$ Dīghanikāya, ii, 211, Majjhimanikāya, ii, 140. This is also referred to at Majjhimanikāya, ii, $166 f$.

70 Taisho Volume 49, 15b.

${ }^{71}$ Dìghanikāya, ii, 133-134. This is also mentioned in all the four Chinese translations: Taisho Volume 1, 19c, 168b-c, 184a, and 198b-c.

72 Some prominent features in the thirty-two marks of the Buddha stipulate that one can immediately recognize him when one meets him. The Buddha, for instance, had long arms so that his palms of both hands could touch and rub against his knees without stooping. He had wheels with a thousand spokes and ribs and complete hubs on the soles of his feet. See the Lakkhanasutta of the Dighanikāya, iii, 142-144.

73 friend

74 Majjhimanikāya, iii, 238-247. Sutta No. 140.

75 W. Rahula, What the Buddha Taught. London: Gordon Fraser, 1985, 7, footnote 2.

${ }^{76}$ Majjhimanikāya, iii, 155.

77 Taisho Volume 2, 629b.

78 W. Pachow, 'A Hermeneutical Approach to the Supernatural Phenomena in Buddhist History.' Chinese Culture, Vol. XXVII, (1986), No.1, 31.

79 navānga or dvādaśānga

${ }^{80}$ The adbhuta-dharma includes three kinds of miracles or wonderful things: the miracles associated with the Buddha, the miracles of the Dharma and the miracles of the arrya Sangha. But, according to the Vibhāṣa (Taisho Volume 27, 660b), the term adbhuta-dharma originally meant the miracles of the Buddha. "What is adbhuta-dharma? It is the accounts in the scriptures of the miracles associated with the Triple Gem (triratna). But other teachers say that it is the accounts of disciples in praise of the Buddha's marvellous deeds or miracles such as Śāriputra who praises the Buddha for his great merit and Ānanda who praises the wonderful things about the Buddha." Here what 'the other teachers say' solely concerns the miracles of the Buddha. It is also said in the Chinese translation of the Lalitavistara: "The adbhuta-dharma is such as Ānanda who praises the Buddha for his wonderful things." (Taisho Volume 4, 643c) But, according to the Mahāprajñāpāramitā Śāstra, "The Buddha manifested various kinds of wonderful things and sentient beings were amazed and thought it was marvellous (adbhuta). This is adbhuta-dharma." (Taisho Volume 25, 308a) So adbhuta-dharma originally only included the miracles of the Buddha. 
81 Anguttaranikāya, ii, 130-135.

${ }^{82}$ Majjhimanikāya, iii, 118-124. The Sanskrit counterpart of this sutta is found in the Chinese Madhyamāgama (Taisho Volume 1, 469c-471c), but it is slightly longer than the Pâli one which narrates the miracles from the appearance of the Bodhisattva in the Tusita Heaven to his birth on earth. The Chinese version includes another ten miracles different from the ones mentioned in the Pāli version.

83 The Bhümicālasutta of the Anguttaranikāya iv. 307. The same sūtra is also found in Taisho Volume 1, 477b-478b. An earthquake is also mentioned in the Chinese Ekottarāgama, T2, 753c-754a.

84 abhijñā

85 Samyuttanikāya, v, 288-290.

86 B. G. Gokhale, New Light on Early Buddhism. London: Sangam Books Limited, 1994, 98.

87 abhijñā

88 The Iddhipāda-Samyutta mentions that both samanas and Brahmins could gain the first five modes of higher knowledge. (Samyuttanikāya, v, 275ff) It is only the Buddhist recluses who could achieve the sixth, the knowledge of āśravas being destroyed.

89 The Dīghanikāya, sutta No. 2, the Dīrghāgama, sūtra No. 27.

90 iddhi-vidhā

91 dibba-sota

92 ceto-pariya-ñāṇa

93 pubbenivāsānussati

94 dibba-cakkhu

95 āsavakkhaya

96 Majjhimanikāya, i, 247-249.

97 The stereotype text of $i d d h i$ found in all the four Sutta collections (e.g. Dighanikāya, i, 78) is as follows: Now, O Bhikkhus, the monk enjoys the various magical powers (iddhi-vidha $)$, such as being one he becomes manifold, and having become manifold he again becomes one. He appears and disappears. Without being obstructed he passes through walls and mountains, just as if through the air. In the earth he dives and rises up again, just as if in the water. He walks on water without sinking, just as if on the earth. Cross-legged he floats through the air, just like a winged bird. With his hand he touches the sun and moon, these so mighty ones, so powerful ones. Even up in the 
Brahma-world he has mastery over his body.

98 Vinaya, Mahāvagga, i, 15-34. The Book of Discipline, iv, 24-46.

99 rddhi

100 Dïghanikāya, ii, 89.

101 Dīghanikāya, ii, 103.

102 Dīghanikāya, ii, 129.

103 Majjhimanikāya, i, 330

104 Majjhimanikāya, ii, 99.

105 Majjhimanikāya, ii, 135.

106 Dìghanikāya, iii, 112-113.

107 The monastic rules concerning the prohibition of performing miracles are found in the Vinaya, ii, 112-113. See also the Cullavagga, v, 8; The Book of Discipline, v, 151.

108 B. G. Gokhale, New Light on Early Buddhism. London: Sangam Books Limited, 1994, 107.

109 The list of the ten powers are found in Majjhimanikāya, i, 69-72; Anguttaranikāya, v, 33-36; the Dīrghāgama, Taisho Volume 2, 41b-c; the Samyuktāgama, Taisho Volume 2, 186c-187a; the Ekottarägama, Taisho Volume 2, 776b-c; 859a. The list of the four kinds of intrepidity is found in Majjhimanikāya, i, 71-72. But both the powers and the four kinds of intrepidity are mentioned in numerous places in the Nikāyas and the Agamas.

110 mahākaruna 